\title{
Human Development and Resource Use in the COASTAL ZONE INFLUENCES ON HUMAN HEALTH
}

\author{
BY ROBERT E. BOWEN, ANAMARIJA FRANKIC, AND MARYE. DAVIS
}

Coastal watersheds and nearshore marine areas are the most valuable and dynamic places on Earth. Human population growth is great in these regions, which are home to some of the most sensitive habitats in the world. Coastal areas provide more than half of the overall service value derived from the global environment (Costanza et al., 1997). Natural (e.g., hurricanes and tsunamis) and human pressures on this environment require it to constantly adjust. More than any other area, the global coast has defined the progress of human culture and continues to be a singular influence in how humans connect to the world around them.

For these reasons and others, the global coast should be a central focus in the environmental management decisions of governments at all levels. However, increasingly, we have come to understand that allowing the degradation and broad-scale change in coastal systems has another consequence-our own health. This theme is well summarized in the Oristano Declaration $^{1}$, which states in part:

...that the global coastal environment is under threats through intensified natural resource utilization brought about by higher densities of settlements, increasing shipping, rapidly growing aquaculture production, expanding tourism activities, massive resource exploitation and other activities. All of these have shown to contribute individually, but more importantly cumulatively, to higher risks for public health and the global burden of disease (Bowen et al., in press).
This article and accompanying case study is a short summative effort to describe the relationships among coastal development, resource use, and human-health risks. Given the breadth and complexity of this larger issue, a strategy to concentrate the discussion is essential. Our choice is to limit our view to those points of opportunity and challenge faced by a single developing nation-Croatia (see case study by Bowen et al., this issue).

Croatia is an extremely useful vehicle to engage this issue. It is a country of the northeast Adriatic, deeply dependent on the sea, and where emerging decisions on the nature of coastal management will make a significant difference in the economic future of the nation. In addition, the international scientific community has identified the Croatian coast as one of the most pristine and rich natural resources in the Mediterranean (WWF, 2003; Frankic, 2005). Croatia is also working to position itself as a tourism destination of note within and beyond Europe. With this case study in mind, three general issues were selected to organize the paper:

- Human population in the coastal zone and hazard vulnerability

- Land-based sources of pollution and seafood consumption

- Enteric (intestinal) pathogens and coastal tourism

These topics will be addressed globally and within the context of the Croatian case study.

'In July of 2003, an international workshop entitled "Marine-based Public Health Risk" was held at the International Marine Center in Sardinia. In attendance were more than two dozen distinguished experts in the myriad integrated fields associated with the oceans and human health. The "Oristano Declaration" evolved from the research, reporting, and debate at that workshop. 


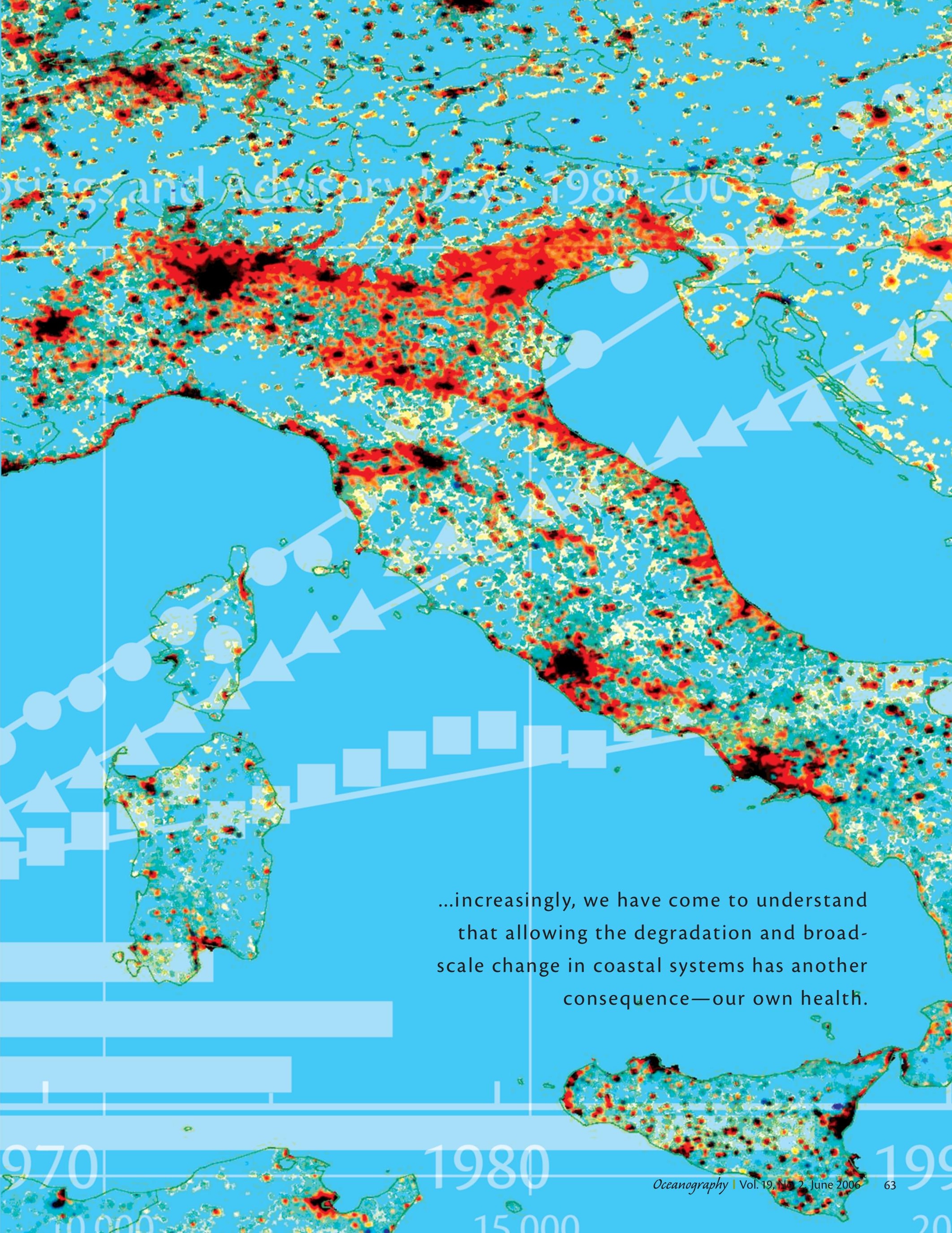




\section{HUMAN POPULATION IN THE COASTAL ZONE AND HAZARD VULNERABILITY}

Estimates of coastal population and rates of population change are essential when focusing the question of coastal development and human health (Hall, 2001). For these purposes, the coastal zone is defined as the immediate coastline to $100 \mathrm{~km}$ inland. This definition directs an acknowledgement of an integrated coastal watershed as the core coastal area. Rigorously constructed estimates vary widely, but it can be safely assumed that between one-quarter and one-half of the global human population lives within the coastal zone. The most rigorous assessment to date is at the lower point in that range; however, it combines various data sources for a common base year (1990), which means that this conclusion does not include recent immigration toward the coast (Small and Nichols, 2003). In the United States, coastal counties contain 53 percent of the nation's population, but only 17 percent of the nation's land area (excluding Alaska). Critically, population densities of coastal counties are about 20 percent higher than non-coastal counties (NOAA,

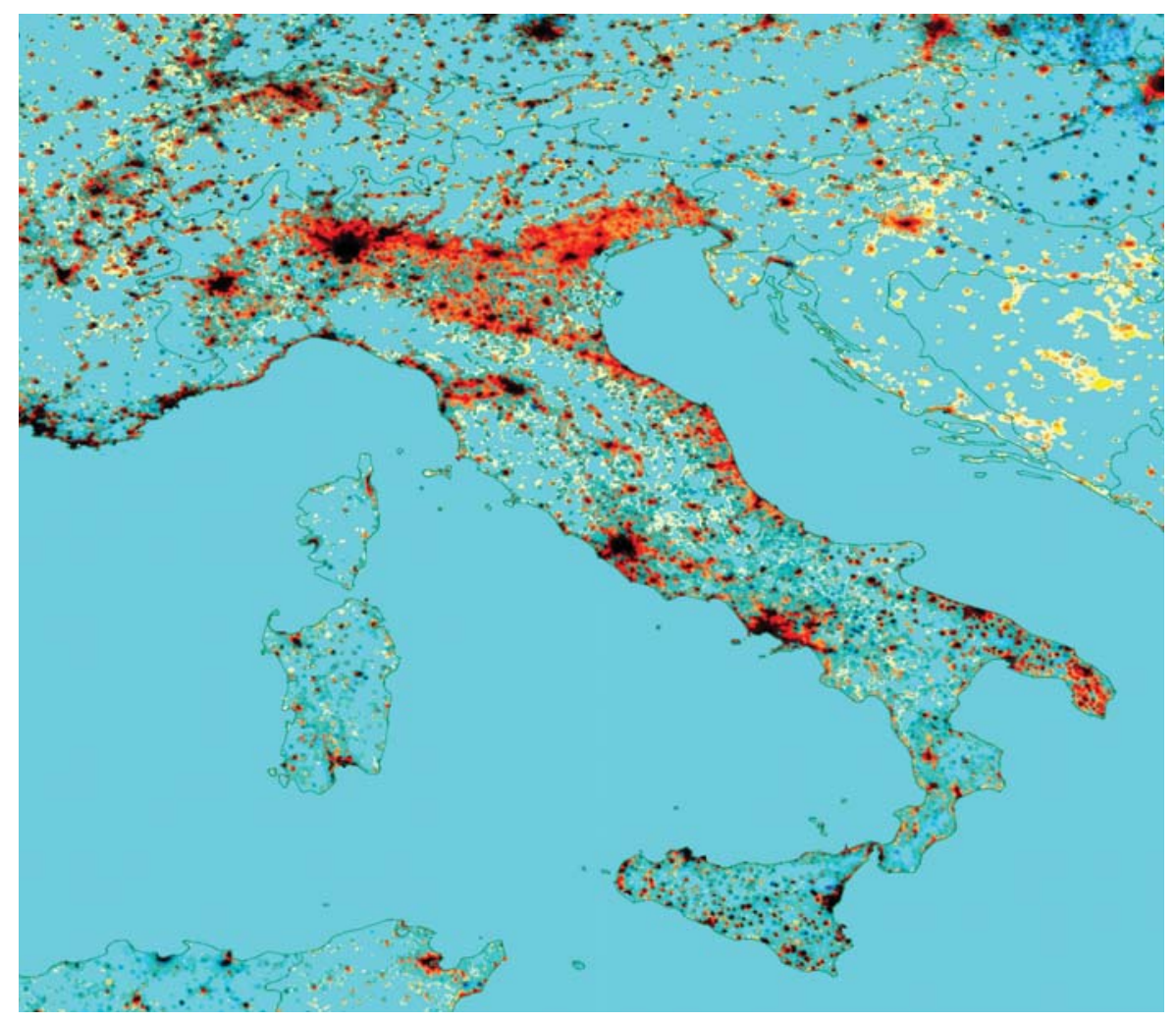

Figure 1. Nightlight Imaging of Italy and the Adriatic. This image conveys the intensity of nightlight from two periods (1993 and 2000). Black denotes no change in light intensity between the two years; yelloworange denotes new areas of human growth. Of particular interest is that this new coastal development occurred in a region of diminishing overall population (population growth rates are less than 2.0 for all countries portrayed in this image). Source: FAO (2005a). Defense Meteorological Satellite Program data and algorithms provided by NOAA/NESDIS National Geophysical Data Center. More information available at: http://dmsp.ngdc.noaa.gov/dmsp.html.
2005). Even with differences in study methods and national trends, it is clear that more people live within the coastal zone today than were alive 50 years ago (Bowen and Crumbley, 1999).

It is essential to emphasize the dynamic nature of coastal populations. The most robust available tool to illustrate this is the maps comparing the intensity of Earth-surface nightlight over time. Figure 1 portrays Earth-surface nightlights during two periods_-1993 and 2000 (FAO, 2005a). This map provides a remarkable visual of coastal population change. It is noteworthy that these changes are evident in a region where all countries register negative total population growth, including Croatia (UNPOPIN, 2005a,b). Also, these changes have occurred over fewer than 10 years, suggesting they would not have been picked up in normal decadal census studies. These population dynamics are important to the present argument. Increased coastal population means a greater number of humans at risk from coastal hazards (such as hurricanes and tsunamis). And, new human settlements replace, or critically fragment, biological habitats (such as mangroves, coral reefs, and coastal wetlands) that (among other

Robert E. Bowen (bob.bowen@umb. edu) is Associate Professor, Department of Environmental, Coastal and Ocean Sciences, University of Massachusetts, Boston, Boston, MA, USA. Anamarija Frankic is Assistant Professor, Environmental, Earth and Ocean Sciences, University of Massachusetts, Boston, Boston, MA, USA. Mary E. Davis is Assistant Professor, Environmental, Earth and Ocean Sciences, University of Massachusetts, Boston, Boston, MA, USA. 
social benefits) provide natural buffers to coastal hazards.

As populations migrate to coastal areas, human susceptibility to ocean and coastal disasters will become an increasingly important political and social issue. These disasters are the result of cyclical and seasonal fluctuations (i.e., hurricane seasons), long-term trends in climate variability, and geologically driven events (e.g., tsunamis). Whatever the underlying causes of these natural disasters, their human health and economic impacts are indisputable. Recent world events have brought ocean-related natural disasters to the forefront of public consciousness, including Hurricane Katrina in the United States and the Asian tsunamis (see article by Keim, this issue and case study by Miller, this issue).

Even a year after landfall, accurate estimates of the loss of life from the December 2004 tsunami are challenging to acquire. What is clear is that between 200,000 and 300,000 people died that day (NYT, 2005; FAO, 2005b). Although the wave heights estimated for certain parts of Banda Aceh and Aceh Provence could have been little mitigated by a broader buffer of natural habitat, the same clearly cannot be said of other areas. Although coastal development did not itself generate the tsunami, the nature of the development, and the associated vulnerability of nearshore populations were factors that increased the risk impact of the event.

The same can be, and has been, said of the devastation of Hurricane Katrina. Even absent speculation about the increased intensity or frequency of great storms being linked to global warming, the level of human risk is a result of the nature and location of coastal development. At least 1,400 peopled died as a result of the storm and associated flooding. With an estimated economic damage loss in excess of US \$ 75 billion, Katrina will mark the costliest tropical cyclone to ever make landfall to date (Knabb et al., 2005).

These two events provide sobering examples of the catastrophic potential of natural disasters on overly populated coastal regions. Although the natural causes leading to these disasters are quite notably different, they both provide parallel lessons for future disaster mitigation and policy response. A fundamental lesson from both events is the differential impact that natural disasters have on socially vulnerable coastal populations. Economic disparities can be mitigated with better information on socio-economic status of at-risk populations, continued assessment of extent and integrity of coastal habitat, effective landuse regulation, and aggressive disaster warning and evacuation (particularly for at-risk populations).

\section{LAND-BASED SOURCES OF POLLUTION AND SEAFOOD CONSUMPTION}

The increasing coastal population around the globe is outpacing the environment's capacity to assimilate human and industrial wastes (see case study by Bowen et al., this issue). Point-source discharges of untreated wastewater and sewage, as well as industrial and agricultural effluents, continue to pollute es- tuarine and coastal systems. The general theme of land-based sources of pollution was addressed by the United Nations at the turn of the millennium (GESAMP, 2001). One core conclusion is particularly noteworthy:

Although there have been some notable successes in addressing problems caused by some forms of marine pollution, and in improving the quality of certain areas, on a global scale marine environmental degradation has continued and in many places even intensified (GESAMP emphasis).

Three broad categories of contaminants will focus the present assessment: (1) industrial organic compounds and metals, (2) un- or under-treated sewage (with a focus on the introduction of enteric pathogens), and (3) agricultural chemicals including fertilizers. Although the impacts on human health of development-driven, land-based sources of pollution must be addressed within an integrated context, the confines of the current effort move us to assess risks of industrial chemicals through seafood consumption and wastewater introduction of enteric pathogens to coastal tourism risk.

\section{Industrial Organics and Metals} Shifts in population concentration bring supporting industries and commercial expansion. The primary international focus in this contaminant class has been on the so-called Persistent Organic Pollutants or "POPs" . Because thousands of new industrial compounds are introduced each year, it is nearly impossible to factor an accurate assessment of the

2 The term "POPs" can be confusing. The literature uses the term to reference (1) the broader class of industrial organic compounds and (2) the group of 12 substances covered by the Stockholm Convention on Persistent Organic Pollutants (POPs) (http://www.pops.int/). The present effort uses the more expansive definition. 

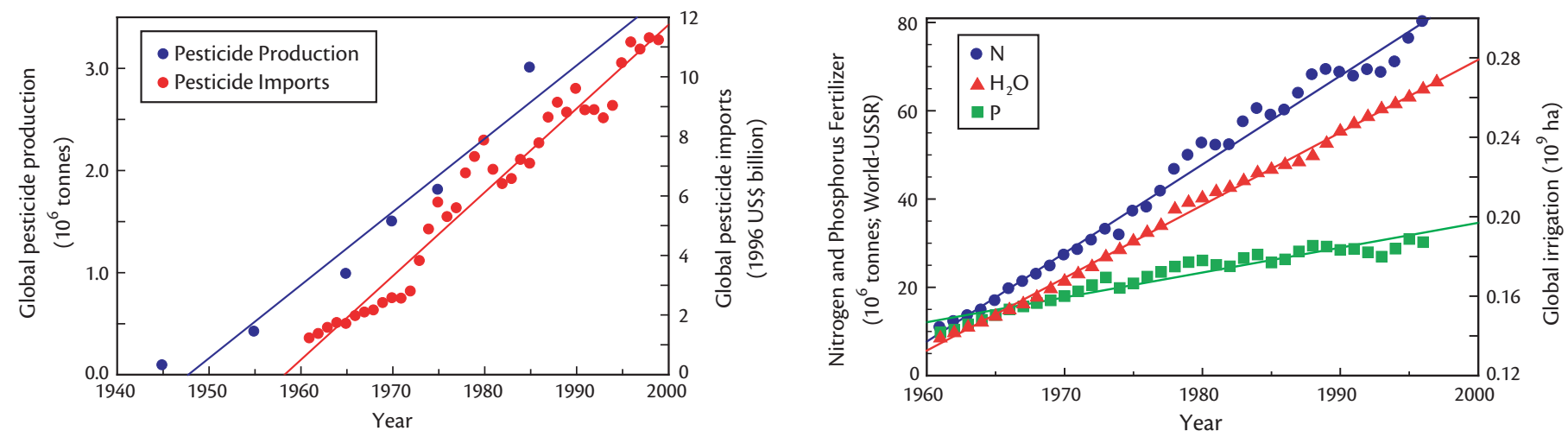

Figure 2. Agricultural chemicals (pesticides and fertilizers) have witnessed significant growth over the past generation. It is essential to manage introduction of these chemicals into coastal watershed systems. Source: Tilman et al. (2002).

total production of organics with potential human health risks. We should recognize, however, that most POPs of contemporary concern in the marine environment are synthetic compounds produced for the benefit of human society. Their beneficial features must be weighed against their negative effects on human health and the environment (GESAMP, 2001) (see article by Dewailley and Knap, this issue and case study by Dewailly, this issue).

However, two points need to be stressed. First, there is a clear and global need for long-term, integrated and sustained efforts to assess environmental conditions in coastal waters. Without better information on the potential and real contaminant burdens bioaccumulated in seafood, accurate assessments of risk potential are impossible. Equally important is the need to comparably and consistently determine the source of disease in humans and levels of seafood consumption by source. While concern over human risk is warranted given available information, true risk values cannot be measured without more determined, comparable, and consistent surveillance systems for seafood-sourced chronic disease. At present, appropriate surveillance programs around the world are, at best, limited and, more often, non-existent (Todd, in press).

\section{Agricultural Chemicals}

Changes in habitation patterns are typically associated with changes in agricultural land use and practices. Figure 2 highlights long-term production levels of both agricultural pesticides and commercial fertilizers (Tilman et al., 2002). Over the last 25 years, total global production of pesticides has more than doubled. These compounds provide essential benefits to humankind by improving access to food and reducing malnutrition. However, as with POPs, these benefits must be viewed within the context of sustainable industrial and agricultural development. Better, more effective, and integrated management of agricultural practices (particularly in coastal watersheds) can mitigate the nutrient impacts of fertilizers and the potentially toxic effects of certain pesticides.

Studies addressing the Adriatic region (including Croatia) and nearby coastal waters suggest a focus on the health risks of mercury and polychlorinated biphenyls PCBs (see case study by Bowen et al., this issue).

\section{Mercury/Methyl Mercury}

Although Mercury $(\mathrm{Hg})$ is a naturally occurring element, it is introduced to the marine environment from both natural and anthropogenic sources. Mercury is the byproduct of many industrial processes, notably coal burning, various manufacturing practices, and waste incineration. Once introduced into the aquatic environment, it is rapidly transformed by bacteria into a more toxic form, methyl mercury (MeHg). This highly lipophilic compound is responsible for mercury's more toxic effects and is biomagnified in the environment (Dewailly et al., 2000), leading to tissue levels in larger organisms (such as humans) that can be much higher than ambient background.

Methyl mercury has both acute and chronic health effects; as a neurotoxin, it is of particular concern in fetal exposure and childhood development (Grandjean et al., 1997, 2003). The acute result of 


\section{CASE STUdy: Croatia}

\section{BY ROBERT E. BOWEN, ANAMARIJA FRANKIC, AND MARY E. DAVIS}

\section{CROATIA AND COASTAL POPULATION}

Croatia is a complex mix of coastline and 1,246 fringing islands. Many of these islands have full-time resident populations, while many others are visited regularly by recreational bathers in season. The Croatian coastline is home to 1.68 million people, which represents about 38 percent of the total national population (WRI, 2005). During the summer, an additional one million tourists visit the coast (MMTPR, 2005). In addition, the Adriatic Sea receives human and industrial waste from a resident watershed population of 15 million. Wastes from this watershed system make up approximately 35 percent of the total pollution load flowing into the Mediterranean (Kucpilic, 2005) (see Bowen et al., in press; Dewailly and Knap, this issue; Dewailly, this issue; Dufour and Wymer, this issue).

\section{CONTAMINANT BURDENS IN CROATIAN SEAFOOD}

The Adriatic Sea is located in the northeastern Mediterranean and is strongly influenced by the Po River watershed. It is characterized by low precipitation, high evaporation, low tidal action, low nutrient content, low suspended load, and low biological productivity. Several studies have addressed the question of contaminant burdens in commercially available fish in or near Croatian waters. Those studies argue that an initial focus on levels of mercury and polychlorinated biphenyls ( $\mathrm{PCBs}$ ) may be warranted (CIESM, 2004).

\section{Mercury}

Several papers concerning concentrations of mercury and methyl mercury in fish caught in the Adriatic and Mediterranean were published between 2000 and 2003. In Storelli and Marcotrigiano (2000, 2001), the total mercury in megrim (112 samples), common sole
(100 samples), striped mullet (312 samples), angler-fish (120 samples), and black-bellied angler (156 samples) caught in the South Adriatic Sea was measured. These species represent a mix of benthic (bottom-feeding) and pelagic (water-column feeding) fish. The benthic anglerfish species contained concentrations of mercury as high as $2.22 \mathrm{mg} / \mathrm{kg}$, with means of $1.3 \mathrm{mg} / \mathrm{kg}$ for anglerfish and $0.7 \mathrm{mg} / \mathrm{kg}$ for black-bellied angler. A correlation between the size of fish and the concentration of methyl mercury was also observed in each species. Regulatory standards vary from country to country; however, $1.0 \mathrm{mg} / \mathrm{kg}$ is generally considered the trigger for management action.

Higher concentrations of methyl mercury were observed in bluefin tuna with a mean of $1.02 \mathrm{mg} / \mathrm{kg}$ for tuna (range, $0.07-4.26 \mathrm{mg} / \mathrm{kg}$ ). Storelli et al. (2002) reported results for mercury/methyl mercury in tuna and sharks taken in the Adriatic Sea. The average concentration of mercury in spiked dogfish (Squalus acanthias) was $6.5 \mathrm{mg} / \mathrm{kg}$ - six times the common regulatory limit. In addition, mercury concentrations in commonly consumed fish in Croatia were examined in 2003. Hake (three samples) was found to contain mercury at an average concentration of $0.375 \mathrm{mg} / \mathrm{kg}$. Anchovies, sardines, bogue, mackerel, and mussels all contained mercury at an average concentration of $<0.28 \mathrm{mg} / \mathrm{kg}$ (Juresa and Blanusa, 2003).

\section{PCBs}

A more limited set of recent studies has revealed levels of concern for $\mathrm{PCB}$ in regional seafood. One study reports on the monitoring of chlorinated hydrocarbons in meat and fish in Croatia. Four hundred and sixty-six fatty-tissue samples of beef, pork, poultry, and fish were assayed between 1992 and 1996 for chlorinated hydrocarbons, including HCB, alpha- $\mathrm{HCH}$, lindane, DDT and metabolites, and total PCBs. Samples were divided into two groups: (1) meat and fish imported to Croatia and (2) meat from Croatian farms and fish from the Adriatic Sea. However, PCB levels in domestic fish were considerably higher (average $0.046 \mathrm{mg} / \mathrm{kg}$ ) than in imported fish $(0.006 \mathrm{mg} / \mathrm{kg}$ ) (Kipcic et al., 2002). Although these absolute numbers do not register an acute health concern, they do suggest levels of domestic product as holding comparatively higher amounts of PCBs than imported norms.

\section{CROATIAN COASTAL TOURISM AND BATHING-WATER QUALITY}

The Mediterranean is the world's number one tourist destination, generating one-third of global tourist revenues. Today, 63 percent of European tourists prefer the coast as a primary holiday destination. In Croatia, recent research suggests that overall tourism contributed 30 percent of total Gross Domestic Product (GDP) (US \$20.6 billion). In 2005, 10 million tourists visited Croatia, and recent government documents have established a goal to achieve 11 million by 2010 (MMTPR, 2005).

A significant risk vector for coastal tourists is direct contact at bathing beaches, with monitoring and beach closing as the dominant management tools. In Croatia, recent monitoring indicates promising results. Water-quality testing at beaches during 2003 and 2004 showed that 98 percent of samples complied with the standards set forth in the "Regulation on Bathing Water Quality Standards" (MZOPU, 2004). This regulation is based on the European Council Directive 76/160/EEC Concerning the Quality of Bathing Water (based on the "Annapolis Protocol"). Sea-water quality at beaches in Croatia has been monitored since 1988 (MZOPU, 2004). 
methyl mercury exposure is damage to the central nervous system (concentrations of $1-2 \mathrm{mg} / \mathrm{kg}$ in brain tissue can produce these effects). Although these short-term, high-concentration exposures are an important public health concern, it is low-level chronic exposure that holds the biggest potential human health threat. Human populations with high seafood consumption have the greatest risk of elevated $\mathrm{MeHg}$ in their tissues and are, therefore, more susceptible to its neurotoxic and development effects. These health concerns are magnified for a developing fetus and young children. Recent studies reported that highest human concentrations and related health effects were found in subsistence fishing populations in far northern latitudes (Marsh et al., 1995; Lebel et al., 1996; Gaggi et al., 1996; Clarkson, 2002).

\section{Polychlorinated Biphenyls}

Polychlorinated biphenyls (PCBs) are man-made chemicals that, unlike mercury, are not naturally encountered in the environment. Although PCBs are no longer manufactured in the United States, the persistent nature of these pollutants leads to human exposure decades beyond chemical production. PCBs consist of 209 individual compounds (also known as congeners) and exposure to each of these compounds is associated with different levels of human-health risks, including carcinogenicity, neurotoxicity, and developmental disabilities (as an endocrine disrupter) (Grandjean et al., 2001; Knap, et al., 2001; IOC, 2001). Similar to methyl mercury, fish consumption remains the major route of exposure to PCBs.

\section{Wastewater Treatment}

Un- and under-treated sewage is the dominant challenge to coastal environmental quality in much of the world (see Dufour and Wymer, this issue; case study by Laws, this issue). Recent history suggests a marginal improvement in global access to wastewater sanitation services. In 1990, for example, 55 percent of the global population had sanitation coverage, which increased to 60 percent by 2000 . However, in areas of highest population growth—high-density rural areas and certain regions (i.e., Asia and Africa) — access to improved wastewater sanitation was well below 50 percent (WHO, 2000). Figure 3 conveys regional differences in sanitation-treatment levels.

Untreated human and animal wastes can introduce pathogens into the coastal environment that present

\section{SANITATION, GLOBAL COVERAGE, 2000}

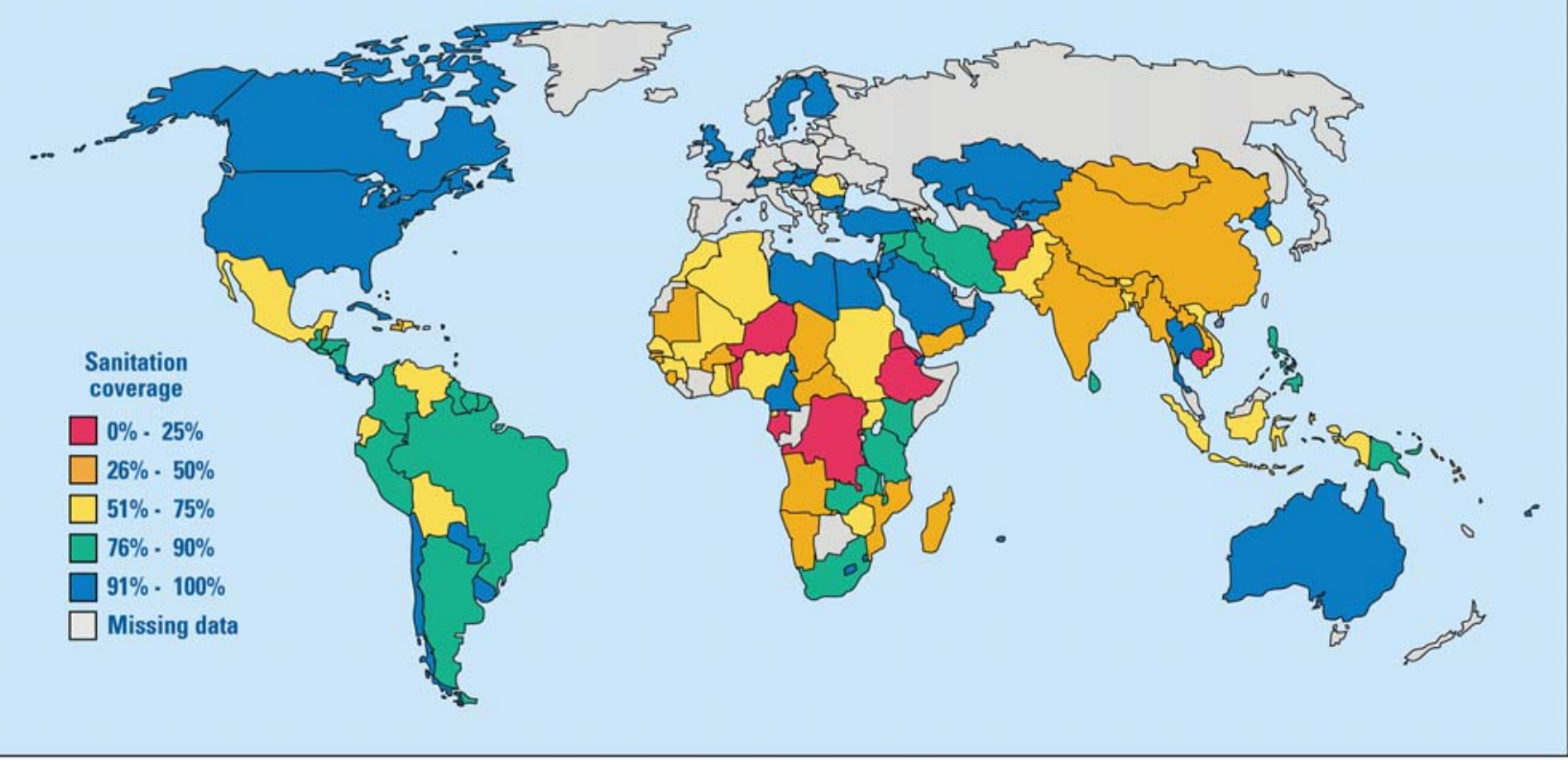

Figure 3. Most areas of the globe with high population growth rates hold the lowest levels of improved sanitation coverage. Source: WHO (2000). 
significant human-health challenges.

The primary route of human exposure to aquatic pathogens is the consumption of contaminated seafood. There is a large amount of epidemiological and toxicological evidence on human risks of infectious disease from this source (NAS/IOM, 1991; Mead et al., 1999; Burke et al., 2000; Shuval, 2003).

\section{ENTERIC PATHOGENS AND COASTAL TOURISM}

Coastal tourism is the largest and fastestgrowing industrial/commercial sector in most coastal regions. Indeed, international tourism has increased nearly 400 percent since 1970, with approximately 700 million international tourist arrivals estimated for 2005 (UNWTO, 2005). While a majority of these tourists are not coastal visitors, a significant minority does visit the coast and bathe in coastal waters (see case study by Laws, this issue). This bathing can be a risk pathway for a variety of human illnesses.

The direct ingestion of seawater and dermal exposure to contaminated water and sediments (Clark et al., 1997; Shuval, 2003) can lead to gastrointestinal, dermal, respiratory, eye, ear, nose, and throat infections. The WHO (1998), for example, has estimated a 5 percent risk exposure for gastrointestinal illness for a healthy bather even in coastal water deemed "acceptable" by national/international standards. For more contaminated waters, the direct contact risk is obviously greater.

The policy response to such human health risks has come largely in the form of improved and increased monitoring of recreational waters and limiting access when warranted. The WHO and the U.S. Environmental Protection Agency (EPA) have proposed a global and integrated monitoring protocol for recreational bathing waters. The so-called "Annapolis Protocol" (WHO, 1999) is an effort to build a universally accepted approach to bathing-risk monitoring.

The importance of monitoring is well represented by the data in Figure 4. They were collected by a coalition of U.S. local, federal, and non-governmental organizations over a fifteen-year period. These data show that the annual number of beach closings has increased exponentially (from around 400 in 1988 to more than 18,000 in 2004) over that period (Dorfman and Stoner, 2004). The overall quality of U.S. coastal waters has not significantly degraded over that period (USEPA, 2001; Pew Oceans Commission, 2003). Rather, these data show that routine monitoring is necessary to understand and manage direct contact risk for recreational bathers.

The more active the monitoring program, the more aggressive governments

Total Number of Beach Closings and Advisory Days: 1988-2003

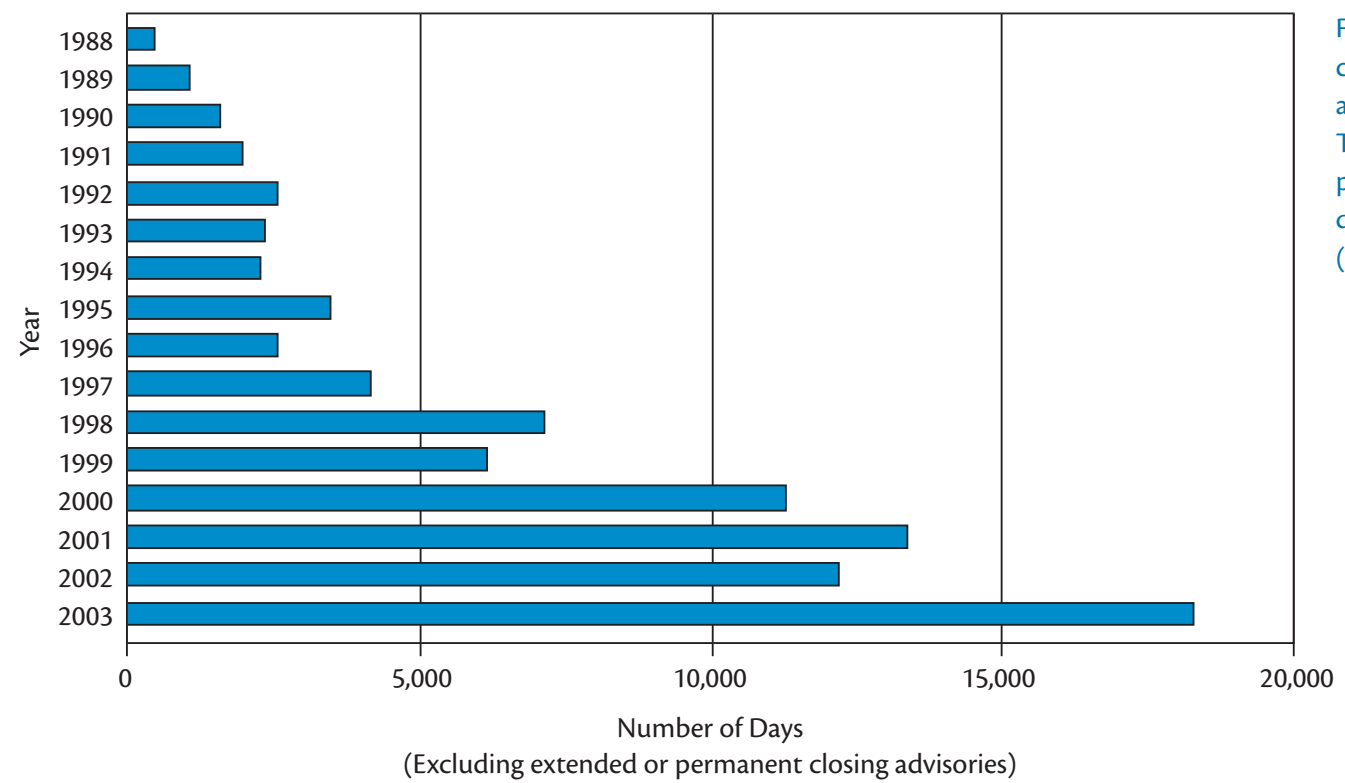

Figure 4. Aggressive monitoring has indicated the need to close beaches to recreational bathing to mitigate risk exposure. This growth in closings is evident during a period when overall coastal environmental quality was either improving or in marginal (not exponential) decline. 
can be in mitigating disease. Governments dependent on coastal tourism, such as Croatia, should look upon the use of internationally sanctioned beachmonitoring programs as clear and certain opportunities to more aggressively manage and market the safety of recreational bathing in coastal waters.

\section{CONCLUSIONS}

A significant body of evidence argues that the dynamics of human coastal populations and associated land-use have imposed increased, and in some instances, substantial human health risks. While we do not suggest governments forgo coastal development, it is increasingly clear that future development must be based on better-informed and more sustainable management practices. During the last fifteen years, enormous effort has been dedicated towards the design of long-term, integrated, and sustained assessment protocols for coastal areas. At the international level, the Global Ocean Observing System (IOC, 1996, 2001, 2003, 2005), the Coastal Panel of the Global Terrestrial Observing System (FAO, 2005a), and the Integrated Global Observing Strategy (http://www. igospartners.org/) have all developed design/implementation plans to address this need.

In the United States, the recent U.S. Commission on Ocean Policy report (2004) called for a domestic integrated and sustained monitoring effort. The United States has created a national office for Integrated and Sustained Ocean Observations (http://ocean.us/) as a response to both global and national efforts. Therefore, the central challenge is not the availability of rigorously defined plans - they are most clearly in place.

Rather, the challenge to governments is to embrace these implementation plans as essential to the sustainable development of coastal regions and as vehicles to mitigate associated public-health risks. 맘

\section{REFERENCES}

Bowen, R.E., and C. Crumbley. 1999. Evolving principles in coastal management: From concept to action. In: Handbook of Global Environmental Policy and Administration, D.L. Soden and B.S. Steel. Marcel Dekker, New York, NY.

Bowen, R.E., H. Halvorson, and M. Depledge, eds. In press. Marine Pollution Bulletin (Special Issue).

Burke, T., J. Litt, and M. Fox. 2000. Linking public health and the health of Chesapeake Bay. Environmental Research Section A 82:143-149.

CIESM. 2004. CIESM Workshop Monographs: Novel contaminants and pathogens in coastal waters. CIESM, Monaco, 116 pp. [Online] Available at: http://www.ciesm.org/online/monographs/Neuchatel04.pdf [last accessed April 3, 2006].

Clark, R.B., C. Frid, and M. Attrill. 1997. Marine Pollution. $4^{\text {th }}$ ed. Clarendon Press, Oxford, United Kingdom, 161 pp.

Clarkson, T. 2002. The three modern faces of mercury. Environmental Health Perspectives 110(Supp. 1):11-23.

Costanza, R., R. d'Arge, R. de Groot, S. Farber, M. Grasso, B. Hannon, S. Naeem, K. Limburg, J. Paruelo, R.V. O'Neill, R. Raskin, P. Sutton and M. Van den Belt. 1997. The value of the world's ecosystem services and natural capital. Nature 387:253-260.

Dewailly, E., P. Ayotte, S. Bruneau, S. Gingras, M. Belles-Isles, and R. Roy. 2000. Susceptibility to infections and immune status in Inuit infants exposed to organochlorines. Environmental Health Perspectives 108(3):205-211.

Dorfman, M., and N. Stoner. 2004. Testing the Waters 2004: A Guide to Water Quality at Vacation Beaches. Natural Resources Defense Council, New York, NY.

Food and Agricultural Organization (FAO). 2005a. Coastal Panel of the Global Terrestrial Observing System (GTOS), Coastal GTOS Phase 1 Implementation Plan. GTOS 36. [Online] Avail-able at: http://www.fao.org/GTOS/gtospub/pub36.html [last accessed April 1, 2006].

Food and Agricultural Organization (FAO). 2005b. UN Atlas of the Ocean, "Indian Ocean Tsunami". [Online] Available at: http://www.oceansatlas. org/index.jsp [last accessed April 1, 2006].

Frankic, A. 2005. A protected environment in the Adriatic Area: A key for sustainable economic development. Pp. 97-101 in Doing
Business with Croatia. Global Market Briefing Publishing, London, United Kingdom.

Gaggi, C., F. Zino, M. Duccini, and A. Renzoni. 1996. Levels of mercury in scalp hair of fishermen and their families from Camara de Lobos-Madeira (Portugal): A preliminary study. Bulletin of Environmental Contamination and Toxicology 56(6):860-865, ISSN:0007-4861.

GESAMP (IMO/FAO/UNESCO-IOC/WMO/WHO/

IAEA/UN/UNEP Joint Group of Experts on the Scientific Aspects of Marine Environmental Protection). 2001. Protecting the Oceans from LandBased Activities: Land-Based Sources and Activities Affecting the Quality and Uses of Marine, Coastal and Associated Freshwater Environment. GESAMP Reports and Studies. No. 71, 162 pp. [Online] Available at: http://gesamp.imo.org/ no71/index.htm [last accessed April 1, 2006].

Grandjean, P., P. Weihe, R.F. White, F. Debes, S. Araki, K. Yokoyama, K. Murata, N. Sorensen, R. Dahl, and P.J. Jorgensen. 1997. Cognitive Deficit in 7-Year-Old Children with Prenatal Exposure to Mercury. Neurotoxicology and Teratology 19(6):417-428.

Grandjean, P., P. Weihe, V.W. Burse., L.L. Needham, E. Storr-Hansen, B. Heinzow, F. Debes, K. Murata, H. Simonsen, P. Ellefsen, E. Jorgensen, N. Keiding, and R.F. White. 2001. Neurobehavioral deficits associated with PCBs in 7 year old children prenatally exposed to seafood neurotoxicants. Neurotoxicology and Teratology 23:305-317.

Grandjean, P., R.F. White, P. Weihe, and P.J. Jorgensen. 2003. Neurotoxicity risk by stable and variable exposure to methylmercury from seafood. Ambulatory Pediatrics 3:18-23.

Hall, C.M. 2001. Trends in ocean and coastal tourism: the end of the last frontier? Ocean and Coastal Management 44:601-618.

Institute of Medicine (IOM). 1991. Evaluating Seafood Safety. National Academy Press, Washington, D.C.

Intergovernmental Oceanographic Commission (IOC). 1996. A Plan for the Assessment and Prediction of the Health of the Ocean: A Module of the Global Ocean Observing System. IOC/INF1044. United Nations Educational Scientific and Cultural Organization (UNESCO), Intergovernmental Oceanographic Commission (IOC), Global Ocean Observing System (GOOS), Paris, France, $48 \mathrm{pp}$.

Intergovernmental Oceanographic Commission (IOC). 2002. Implementation Plan for the Health of the Oceans Panel of the Global Ocean Observing System. GOOS Report No. 99. United Nations Educational Scientific and Cultural Organization (UNESCO), Intergovernmental Oceanographic Commission (IOC), Global Ocean Observing System (GOOS), Paris, France, 75 pp. [Online] Available at: http://ioc.unesco.org/goos/docs/ 
GOOS_099_HOTO_design_plan_3.pdf [last accessed April 1, 2006].

Intergovernmental Oceanographic Commission (IOC). 2003. The Integrated Strategic Design Plan for the Coastal Ocean Observations Module of the Global Ocean Observing System (GOOS). GOOS Report No. 125. United Nations Educational Scientific and Cultural Organization (UNESCO), Intergovernmental Oceanographic Commission (IOC), Global Ocean Observing System (GOOS), Paris, France, 190 pp. [Online] Available at: http://ioc.unesco.org/goos/docs/ GOOS_125_COOP_Plan_en.pdf [last accessed April 1, 2006].

Intergovernmental Oceanographic Commission (IOC). 2005. An Implementation Strategy for the Coastal Module of the Global Ocean Observing System. GOOS Report No. 148. United Nations Educational Scientific and Cultural Organization (UNESCO), Intergovernmental Oceanographic Commission (IOC), Global Ocean Observing System (GOOS), Paris, France. [Online] Available at: http://ioc.unesco.org/GOOS/docs/GOOS-148COOP-highres.pdf [last accessed May 6, 2006].

Juresa, D., and M. Blanusa. 2003. Mercury, arsenic, lead, and cadmium in fish and shellfish from the Adriatic Sea. Food Additives and Contaminants 20:241-246.

Kipcic, D., J. Vukusic, and B. Sebecic. 2002. Monitoring of chlorinated hydrocarbon pollution of meat and fish in Croatia. Food Technology and Biotechnology 40(1):39-47.

Knap, A., É. Dewailly, C. Furgal, J. Galvin, D. Baden, R.E. Bowen, M. Depledge, L. Duguay, L. Flemming, T. Ford, F. Moser, R. Owen, W.A. Suk, and U. Unluata. 2001. Indicators of ocean health and human health: A research framework. Environmental Health Perspectives 110(2):839-845.

Knabb, R.D., J.R. Rhome, and D.P. Browne. 2005. Tropical Cyclone Report: Hurricane Katrina, 23-30 August 2005. [Online] Available at: http:// www.nhc.noaa.gov/pdf/TCR-AL122005_Katrina. pdf [last accessed April 1, 2006].

Kucpilic, G. 2005. Anthropogenic inputs, ecological state and impacts on biodiversity in the marine environment. Report contribution to UNDP/ GEF Coast Project, Croatia, 50 pp.

Lebel J., D. Mergler, M. Lucotte, M. Amorim, J. Dolbec, D. Miranda, G. Arantes, U. Rheault, and P. Pichet. 1996. Evidence of early nervous system dysfunction in Amazonian populations exposed to low-levels of methylmercury. Neurotoxicology 17(1):157-168.

Marsh, D.O., M.D. Turner, J.C. Smith, P. Allen, and N. Richdale. 1995. Fetal methylmercury study in a Peruvian fish-eating population. Neurotoxicology 16(4):717-726.

Mead, P., L. Slutsher, V. Dietz, L. McCaig, J. Bresee, C. Shapiro, P. Griffin, and R. Tauxe. 1999. Food- related illness and death in the United States. Emerging Infectious Diseases 5(5):607-625.

Ministry for Environmental Protection and Physical Planning (MZOPU). 2004. Sea bathing water quality in the territory of the Republic of Croatia in 2003 and 2004. [Online] Available at: http:// www.mzopu.hr/doc/Kakvoca_engleska03052005. pdf [last accessed April 1, 2006].

Ministry of the Sea, Tourism, Transport and Development of Croatia (MMTPR). 2005. [Online] Available at: http://www.mmtpr.hr [last accessed April 1, 2006].

National Oceanic and Atmospheric Administration (NOAA). 2005. Population Trends Along the Coastal United States: 1980-2008. U.S. Department of Commerce, National Oceanic and Atmospheric Administration, Spatial Trends in Coastal Socioeconomics (STICS), Silver Spring, MD. [Online] Available at: http://marineeconomics. noaa.gov/socioeconomics/Assesment/population/welcome.html [last accessed April 1, 2006].

New York Times (NYT). 2005. "Tsunami's Legacy: Extraordinary Giving and Unending Strife, December 25, 2005, p. 1.

Pew Oceans Commission. 2003. America's Living Oceans: Charting a Course for Sea Change. Pew Oceans Commission, Arlington, VA.

Shuval, H. 2003. Estimating the Global Burden of Thalassogenic Disease: Human Infectious Disease Caused by Wastewater Pollution of the Marine Environment. The Journal of Water and Health 1(2):53-64.

Small, C., and R. Nicholls. 2003. A Global Analysis of Human Settlement of Coastal Zones. Journal of Coastal Research 19(3):584-599.

Storelli, M.M. and G.O. Marcotrigiano. 2000. Fish for human consumption: Risk for contamination by mercury. Food Additives and Contaminants 17:1,007-1,011.

Storelli, M.M., and G.O. Marcotrigiano. 2001. Total mercury levels in muscle tissue of sword fish ( $X i$ phias gladius) and bluefin tuna (Thunnus thynnus) from the Mediterranean Sea. Journal of Food Protection 64:1,058-1,061.

Storelli, M.M., R. Giacominelli Stuffler, and G.O. Marcotrigiano. 2002. Total and methylmercury residues in tuna-fish from the Mediterranean Sea. Food Additives and Contaminants 19(8):715-720.

Tilman, D., K. Cassman, P. Matson, R. Naylor, and S. Polasky. 2002. Agricultural sustainability and intensive production practices. Nature 418:671677.

Todd, E. In Press. Challenges to Global Surveillance of Disease Patterns. In: The Ocean and Human Health in R.E. Bowen, H. Halvorson and M. Depledge, eds. Marine Pollution Bulletin (Spec. Issue).

United Nations, Population Division of the Department of Economic and Social Affairs of the
United Nations Secretariat (UNPOPIN). 2005a. World Urbanization Prospects: The 2003 Revision. [Online] Available at: http://www.un.org/popin/ functional/population.html [last accessed April $1,2006]$.

United Nations, Population Division of the Department of Economic and Social Affairs of the United Nations Secretariat (UNPOPIN). 2005b. World Population Prospects: The 2004 Revision. [Online] Available at: http://www.un.org/popin/functional/population.html [last accessed April 1, 2006].

United Nations, World Tourism Organization (UNWTO). 2005. WTO Tourism Highlights, Edition 2005. [Online] Available at: http://www.worldtourism.org/facts/menu.html [last accessed April $1,2006]$.

U.S. Environmental Protection Agency (USEPA). 2001. National coastal condition report. EPA620/R-01. EPA, Washington, D.C., 204 pp.

U.S. Commission on Ocean Policy. 2004. An Ocean Blueprint for the $21^{\text {st }}$ Century. [Online] Available at: http://www.oceancommission.gov/documents/full_color_rpt/welcome.html\#final [last accessed April 1, 2006].

World Health Organization (WHO). 1998. Draft Guidelines for Safe Recreational-Water Environments: Coastal and Fresh Waters. Draft for Consultation. EOS/DRAFT/98.14. World Health Organization, Geneva, Switzerland.

World Health Organization (WHO). 1999. HealthBased Monitoring of Recreational Waters: The Feasibility of a New Approach (the "Annapolis Protocol"). Outcome of an expert consultation, Annapolis, USA. Co-sponsored by U.S. Environmental Protection Agency. WHO/SDE/ WSH/99.1. World Health Organization, Geneva, Switzerland.

World Health Organization (WHO). 2000. Global Water Supply and Sanitation Assessment 2000. Report. World Health Organization, Geneva, Switzerland. [Online] Available at: http://www. who.int/docstore/water_sanitation_health/Globassessment/GlobalTOC.htm [last accessed April $1,2006]$.

World Resources Institute (WRI). 2005. Earth Trends: The Environmental Information Portal. Country Profiles. World Resources Institute, Washington, D.C. [Online] Available at: http:// earthtrends.wri.org [last accessed April 1, 2006].

World Wildlife Fund (WWF). 2003. Do Governments Protect the Treasures of our Seas? Measuring Progress on MPAs. World Wildlife Fund, Gland, Switzerland [Online] Available at: http:// www.panda.org. [last accessed April 1, 2006]. 